\title{
Performance Evaluation of Panam Canal Delivery System in Middle Gujarat, India
}

\author{
Deepak Kumar $^{1 *}$ and M. K. Tiwari ${ }^{2}$ \\ ${ }^{1}$ Department of Soil and Water Conservation Engineering, CAET, JAU, Junagadh, \\ Gujarat-362001, India \\ ${ }^{2}$ Department of Irrigation and Drainage Engineering, CAET, AAU, \\ Godhra, Gujarat-389001, India \\ *Corresponding author
}

A B S T R A C T

Ke y w o r d s
Irrigation
scheduling,
Performance
measures,
Adequacy
dependability

Keywords

Irrigation scheduling, measures, Adequacy

Article Info

Accepted: Available Online: 10 April 2020

\section{Introduction}

The irrigated agriculture in India that accounts for nearly $56 \%$ of all food grain production in the country $(1,2)$ consumes around $87 \%$ of the developed water resources of the country (3). Still there has been large deficiency of agricultural water during the period other than the short duration rainy/ monsoon season, which provides enough rainfall for few months only. Due to the large spatial and temporal variability in the rainfall, water resources distribution in the country is highly skewed.

The per capita availability of water, which was 1901 cubic meter (cu m) per year in 2001, considering the population of 1027 million and renewable water resources as 1953 billion cubic meters (b cu m), will 
reduce to $1518 \mathrm{cu} \mathrm{m}$ per year with the projected population by 2025. Performance assessment is an integral part of improving management in business systems and it is equally applicable in irrigation systems in India and elsewhere.

Performance assessment is an activity that supports the planning and implementation process $(4,5)$. (6) Enumerated the necessity of conducting performance evaluations of completed projects from time to time. It was stated that such studies help in (i) assessing the efficiency of projects, (ii) learning whether projects are performing as expected, (iii) devising and implementing remedial measures to improve efficiency of the system wherever warranted.

\section{Materials and Methods}

\section{Study area}

\section{Location}

The study area is located in Godhra, Veganpur, and Sahera village, which comes under the periphery of Panchmahal district in Gujarat state. It is commanded by the $23-\mathrm{R}$, 27/R, 28/R, 29/R and 33-R distributary which is a part of the Panam irrigation project. The Cultural Command Area (CCA) of 23-R, 27/R, 28/R, 29/R and 33-R distributary are 2070 ha, 1620 ha, 681 ha, 1820 ha, and 149 ha, respectively. It is a multipurpose project constructed on Panam River, a tributary of Mahi.

The 23-R distributary is located at around $22.95^{\circ} \mathrm{N}$ latitude and $73.63^{\circ}$ East longitude near Sahera City. The 27-R, 28-R and 29-R distributaries are located at around $22.7884^{\circ}$ North latitude and $73.4995^{\circ}$ East longitude near Veganpur Village and 33-R distributary are located at around $22.7788^{\circ}$ North latitude and $73.6143^{\circ}$ East Longitude near Godhra city. A Location Map of study Area is presented in Figure 1.

\section{Climate}

The study area experiences the similar climatic condition as that of the Panam basin which contains two climatic regions, the northern part of the basin comprises subtropical wet climate (generally basin area occupied by Rajasthan). The major part of basin comprises tropical wet climate, caused mainly due to existence of Vindhyas \& the Western Ghats. The project area experiences minimum temperature of $4.8^{\circ} \mathrm{C}$ in January and maximum temperature $43.5^{\circ} \mathrm{C}$ in May. Average annual rainfall in the area is $940 \mathrm{~mm}$. About $80 \%$ of the rainfall occurs during July and August. On an average there are only 35 to 40 rainy-days per annum, which mostly fall during the period mid - June to midSeptember. There are frequent dry spells occurring over years.

\section{Major crops}

The major crops grown in the study area are Paddy, Castor, Jowar/Bajra/Maize and Wheat. Paddy is the major crop cultivated during Kharif season and wheat is the major crop grown in Rabi season.

\section{Soil}

The soils of the study area are medium textured. Depending upon the land types, physical as well as chemical properties of soil vary markedly. The soils are slightly alkaline in nature with $\mathrm{pH}$ value ranging between 7.9 and 8.2 (Table 1).

\section{Irrigation}

In the study area canal irrigation system is mostly in use. Irrigation water is diverted from the Panam reservoir through a network 
of canals including the Panam main canal, 23/R, 27/R, 28/R, 29/R and 33/R distributaries and their minors, water courses and field channels etc. Irrigation details of 23/R, 27/R, 28/R, 29/R and 33/R distributaries are given in following table 2 .

\section{Canal performance measures}

$(7,8)$ developed the performance measures for analysis of irrigation water delivery systems in terms of adequacy $\left(\mathrm{PI}_{\mathrm{A}}\right)$, efficiency $\left(\mathrm{PI}_{\mathrm{EF}}\right)$, dependability $\left(\mathrm{PI}_{\mathrm{D}}\right)$ and equity $\left(\mathrm{PI}_{\mathrm{E}}\right)$ of water delivery system. They suggested that these performance measures can be incorporated in regular monitoring program which can provide the frame work for assessing the system improvement alternatives.

The performance indicators expressed in terms of measurable quantities are called state variables. The major state variables that determine water-delivery-system performance may be defined in terms of an amount of water $\mathrm{Q}$, which may be referred to either rate, volume, frequency, or duration of water delivery. In the present study, the main focus was on rates and volumes of water delivery. At a point $\mathrm{x}$ in the system and at time $\mathrm{t}$.

$\mathrm{QD}_{D}(\mathrm{x}, \mathrm{t})$ : Actual amount of water delivered to the system at a point ' $x$ ' in time ' $t$ '.

$\mathrm{Q}_{\mathrm{R}}(\mathrm{x}, \mathrm{t})$ : Actual amount of water required for consumptive and other uses downstream of the delivery point $\mathrm{x}$.

$\mathrm{CV}_{\mathrm{T}}$ : Temporal coefficient of variation over the standard time period $\mathrm{T}$.

$\mathrm{CV}_{\mathrm{R}}$ : Spatial coefficient of variation over the region $\mathrm{R}$.

These state variables are combined in various forms to develop indicators of performance viz. $\mathrm{PI}_{\mathrm{A}}, \mathrm{PI}_{\mathrm{EF}}, \mathrm{PI}_{\mathrm{D}}$, and $\mathrm{PI}_{\mathrm{E}}$ (Molden and Gates 1990).

\section{Adequacy $\left(\mathbf{P I}_{\mathbf{A}}\right)$}

A fundamental concern of water-delivery systems is to deliver the amount of water required to adequately irrigate crops. The required amount, determined as that needed to achieve the given agricultural policy, is a function of the area of land irrigated, crop consumptive-use requirements, crop-water production functions, application losses, and cultural practices, such as land preparation and salt leaching. Adequacy of delivery is dependent on water supply, specified delivery schedules, the capacity of hydraulic structures to delivery water according to the schedules, and the operation and maintenance of hydraulic structures. Point performance function relative to adequacy $\left(\mathrm{PI}_{\mathrm{A}}\right)$ is given by:

$$
\mathrm{PI}_{\mathrm{A}}=\frac{1}{T} \sum_{T}\left(\frac{1}{R} \sum_{R} P_{A}\right)
$$

Where, $\mathrm{P}_{\mathrm{A}}=\frac{\frac{Q_{D}}{Q_{R}}}{Q_{R}}$ if $\mathrm{Q}_{\mathrm{D}} \leq \mathrm{Q}_{\mathrm{R}}$
$\mathrm{P}_{\mathrm{A}}=1$, otherwise

Where, $\mathrm{P}_{\mathrm{A}}=$ Point performance function relative to adequacy.

\section{Efficiency $\left(\mathbf{P I}_{\mathrm{EF}}\right)$}

Resource conservation plays an important role in water delivery because water saved may result in less expenditure on infrastructure and can possibly be allocated to fully meet existing requirements or irrigate more land. Conveyance efficiency, which indicates the relative amount of water lost in reach due to canal seepage and overflow, is typically used to address the objective of efficiency in irrigation and water-delivery systems. Another type of overuse, or loss, of water not directly reflected in the concept of 
conveyance efficiency is the delivery of a more than adequate supply of water to diversion points within the system. A waterdelivery system that delivers a greater than adequate supply does not conserve water resources. Additionally, excess water deliveries to farms promote conditions of water logging and salinity. Water-delivery efficiency incorporates the concept of conveyance efficiency, since water requirements at a point of delivery include expected downstream losses.

$$
\begin{gathered}
\mathrm{PI}_{\mathrm{EF}}=\frac{1}{T} \sum_{T}\left(\frac{1}{R} \sum_{R} P_{E F}\right) \\
\text { Where, } \mathrm{P}_{\mathrm{EF}}=\frac{\frac{Q_{R}}{Q_{D}}}{} \text {, for } \mathrm{Q}_{\mathrm{R}} \leq \mathrm{Q}_{\mathrm{D}} \\
\mathrm{P}_{\mathrm{EF}}=1, \text { otherwise }
\end{gathered}
$$

\section{Dependability $\left(\mathbf{P I}_{\mathbf{D}}\right)$}

Dependability is defined as temporal uniformity of the ratio of the delivered amount of water to the required or scheduled amount. A system that performs in a constant manner may be considered dependable. Dependability of water delivery is important to farmers because it allows for proper planning. A system that dependably delivers an inadequate amount of water may be more desirable than one that delivers on the average an adequate yet unpredictable supply. A farmer can plan for a dependable delivery of an inadequate supply of water by planting less or growing different crops or adjusting other farming inputs. However, a farmer cannot easily plan when the supply of water is unpredictable.

$$
\mathrm{PI}_{\mathrm{D}}=\frac{1}{R} \sum_{R} C V_{T}\left(\frac{Q_{D}}{Q_{R}}\right)
$$

Where, $\mathrm{CV}_{\mathrm{T}}\left({ }^{\overline{Q_{R}}}\right)=$ Temporal coefficient of variation (ratio of standard deviation to mean) $\underline{Q_{D}}$

of the ratio $\left({ }^{Q_{R}}\right)$ over the time period $\mathrm{T}$.

\section{Equity $\left(\mathbf{P I}_{\mathbf{E}}\right)$}

Equity is related to water-delivery systems, can be defined as the delivery of a fair share of water to users throughout a system. A share of water represents a right to use a specified amount. The fair share of water may be based on a legal right for water, as in a prior appropriation system, or may be set as a fixed proportion of a water supply, as is done in many rotational delivery schemes. Equity of water delivery is a difficult objective to measure because there are many factors that determine the meaning of a "fair share," and because a fair share is often interpreted subjectively. However, it is important to define measures rating to equity so that systems can be designed or rehabilitated to deliver water in an impartial manner to users served by the system. Equity has been as spatial uniformity of the ratio of the delivered amount of water to the required or scheduled amount. Performance measure relative to equity is given by,

$$
\mathrm{PI}_{\mathrm{E}}=\frac{1}{T} \sum_{T} C V_{R}\left(\frac{Q_{D}}{Q_{R}}\right)
$$

Where, $\operatorname{CV}_{\mathrm{R}}\left(^{\frac{Q_{D}}{Q_{R}}}\right)=$ spatial coefficient of variation (ratio of standard deviation to mean) of the ratio $\left(\frac{Q_{D}}{Q_{R}}\right)$ over the region $\mathrm{R}$.

The standards for these indicators are furnished in Table 3.

The table 3 show that, in order to assess the performance measures daily canal flow data for all the five distributaries under the Panam Canal command was collected from office of the Executive Engineer, Panam Canal Irrigation Project Subdivision No-2,3 and 4, Sahera, Veganpur and Godhra Gujarat and were converted to monthly and seasonal volumetric flow. The delivery performance of 23/R, 27/R, 28/R, 29/R and 33/R distributary 
was carried out under six different supply based irrigation scheduling approaches as listed below:
a) Approach-I: Under existing cropping pattern
b) Approach-II: One decade advance cropping pattern
c) Approach-III: One decade delayed Cropping pattern
d) Approach-IV: Two Decade Delayed Cropping Pattern
e) Approach-V: One fortnightly advance cropping pattern
f) Approach-VI: One fortnightly delayed Cropping Pattern

\section{Results and Discussion}

Performance measures of panam canal command during 2015-16

\section{Performance measures of panam canal command under existing condition of cropping pattern}

The total operation periods during the crop year 2015-16 for the distributaries such as 23R, 27-R, 28-R, 29-R and 33-R were 137, 108, 70,85 and 41 days, respectively. This variation was mainly due to supply position in the Panam canal command.

\section{Adequacy $\left(\mathrm{PI}_{\mathrm{A}}\right)$}

The Adequacy Index for the Panam canal irrigation project under existing cropping pattern in the year 2015-16 is presented in Figure 2. The Adequacy during the month of March was in range of 0.80-0.89 which indicate 'Fair' performance, whereas in the remaining months adequacy being less than 0.80 indicates poor performance.

The Comparatively better value of $\mathrm{PI}_{\mathrm{A}}$ in the month of March than that of another month of
Rabi Season is due to delivery of adequate amount of irrigation water. Overall, with an average value of $\mathrm{PI}_{\mathrm{A}}$ as 0.57 in $23-\mathrm{R}, 27-\mathrm{R}$, 28-R, 29-R and 33-R Distributary of Panam Canal Irrigation project indicates a 'poor' performance of the system as far as the adequacy is concerned. The low values of $\mathrm{PI}_{\mathrm{A}}$ were mainly due to uneven distribution of irrigation water supply in the Rabi season.

\section{Efficiency $\left(\mathbf{P I} \mathbf{E F}_{\mathbf{E F}}\right.$}

The average value of $\mathrm{PI}_{\mathrm{EF}}$ in Panam canal command under existing cropping pattern for the year 2015-16 was 0.86 that indicates a 'good' performance. The $\mathrm{PI}_{\mathrm{EF}}$ values were in range of $0.85-1.0$ during November, December January and February. It indicates that the system was efficient to meet the requirements of the region. The $\mathrm{PI}_{\mathrm{EF}}$ values were in range of less than 0.70 during March month that indicates a 'poor' performance. It indicates that the system was inefficient to meet the requirement of region (Fig. 3).

\section{Dependability $\left(\mathbf{P I}_{\mathbf{D}}\right)$}

The Performance index relative to dependability was done based on their respective turns for year 2015-16 in order to assess the dependency of the farmers on canal water over the year within the Panam canal command. The spatial variations in terms of $\mathrm{PI}_{\mathrm{D}}$ in the Panam canal irrigation project under existing cropping pattern for the year 2015-16 were worked out and are presented in Figure 4.

During the year 2015-16, the calculated values of $\mathrm{PI}_{\mathrm{D}}$ were above 0.2 , indicating 'poor' performance in terms of dependability of the system. It indicates that the water deliveries were not uniform over time in accordance to demand, thus poor timeliness. The average value of $\mathrm{PI}_{\mathrm{D}}$ for the year 2015-16 under existing cropping pattern was 0.58 . 


\section{Equity $\left(\mathbf{P I}_{\mathbf{E}}\right)$}

The average value $\mathrm{PI}_{\mathrm{E}}$ in Panam canal command under existing cropping pattern for the year 2015-16 was 0.63, which falls above the upper limits accounting to 'poor' performance. The higher values of Equity indicate inequitable distribution. The monthly $\mathrm{PI}_{\mathrm{E}}$ values for the crop year 2015-16 are presented in figure 5 .

\section{Performance measures of panam canal command under one decade advance cropping pattern}

\section{Adequacy $\left(\mathbf{P I}_{\mathbf{A}}\right)$}

The Adequacy Index for the Panam canal Irrigation Project under one decade advance cropping pattern in the year 2015-16 is presented in figure 6. The Adequacy during the month of March was greater than 0.90 which indicate 'good' performance, whereas in the month if February adequacy was in range of 0.80-0.89 which indicates 'fair' performance. The comparatively better value of $\mathrm{PI}_{\mathrm{A}}$ in the month of March and February than that of another month of Rabi Season is due to delivery of adequate amount of irrigation water. Overall, with an average value of $\mathrm{PI}_{\mathrm{A}}$ as 0.60 in Panam Canal Irrigation project indicates a 'poor' performance of the system as far as the adequacy is concerned. The low values of $\mathrm{PI}_{\mathrm{A}}$ were mainly due to uneven distribution of irrigation water supply in the Rabi season.

\section{Efficiency $\left(\mathbf{P I}_{\mathrm{EF}}\right)$}

The average value of $\mathrm{PI}_{\mathrm{EF}}$ in Panam canal command under one decade advance cropping pattern for the year 2015-16 was 0.769 that indicates a 'Fair' performance. The $\mathrm{PI}_{\mathrm{EF}}$ value was greater than 0.85 during the month of November and January which indicate 'good' performance (Fig. 7). It indicates that the system was efficient to meet the requirements of the region. The $\mathrm{PI}_{\mathrm{EF}}$ values were in range of 0.70-0.84 during the month of December and February which indicate 'Fair' performance. The $\mathrm{PI}_{\mathrm{EF}}$ values were less than 0.70 during March month that indicates a 'poor' performance. It indicates that the system was inefficient to meet the requirement of region.

\section{Dependability ( $\left.\mathbf{P I}_{\mathbf{D}}\right)$}

The Performance index relative to dependability was done based on their respective turns for year 2015-16 in order to assess the dependency of the farmers on canal water over the year within the Panam Canal Command under One decade advance cropping pattern. The spatial variations in terms of $\mathrm{PI}_{D}$ in the Panam canal for the year 2015-16 were worked out and are presented in figure 8. During the year 2015-16, the calculated values of $\mathrm{PI}_{\mathrm{D}}$ were above 0.2, indicating 'poor' performance in terms of dependability of the system. It indicates that the water deliveries were not uniform over time in accordance to demand, thus poor timeliness. The average value of $\mathrm{PI}_{\mathrm{D}}$ for the year 2015-16 under the one decade advanced cropping pattern was 0.68 .

\section{Equity $\left(\mathbf{P I}_{\mathbf{E}}\right)$}

The average value $\mathrm{PI}_{\mathrm{E}}$ in Panam Canal Command under one decade advance cropping pattern for the year 2015-16 was 0.524 , which falls above the upper limits accounting to 'poor' performance. The $\mathrm{PI}_{\mathrm{E}}$ value was less than 0.25 for the month February and March that indicates 'good' performance. In month of February and March, equitable distribution of canal water takes place in the Panam Canal, whereas higher values in other months indicate inequitable distribution. The monthly $\mathrm{PI}_{\mathrm{E}}$ values for the crop year 2015-16 are presented in figure 9 . 


\section{Performance measures of panam canal command under one decade delayed cropping pattern}

\section{Adequacy $\left(\mathbf{P I}_{\mathbf{A}}\right)$}

The Adequacy Index for the Panam canal irrigation project under one decade delayed cropping pattern in the year 2015-16 is presented in figure 10. The Adequacy of Panam canal command during Rabi season was found to be less than 0.80 which indicate 'poor' performance. Overall, with an average value of $\mathrm{PI}_{\mathrm{A}}$ as 0.49 in Panam Canal Irrigation project indicates a 'poor' performance of the system as far as the adequacy is concerned. The low values of $\mathrm{PI}_{\mathrm{A}}$ were mainly due to uneven distribution of irrigation water supply in the Rabi season.

\section{Efficiency $\left(\mathbf{P I}_{\mathrm{EF}}\right)$}

The average value of $\mathrm{PI}_{\mathrm{EF}}$ in Panam canal Command under one decade delayed cropping pattern for the year 2015-16 was 0.86 that indicates a 'Good' performance. The $\mathrm{PI}_{\mathrm{EF}}$ value was greater than 0.85 during the month of November, January and February which indicate 'good' performance. It indicates that the system was efficient to meet the requirements of the region. The $\mathrm{PI}_{\mathrm{EF}}$ values were in range of 0.70-0.84 during the month of December and March which indicate 'Fair' performance (Fig. 11).

\section{Dependability $\left(\mathbf{P I}_{\mathbf{D}}\right)$}

The performance index relative to dependability was done based on their respective turns for year 2015-16 in order to assess the dependency of the farmers on canal water over the year within the Panam Canal Command. The spatial variations in terms of $\mathrm{PI}_{\mathrm{D}}$ in the Panam canal for the year 2015-16 were worked out and are presented in figure
12. During the year 2015-16, the calculated values of $\mathrm{PI}_{\mathrm{D}}$ were above 0.2 , indicating 'poor' performance in terms of dependability of the system. It indicates that the water deliveries were not uniform over time in accordance to demand, thus poor timeliness. The average value of $\mathrm{PI}_{\mathrm{D}}$ for the year 2015-16 was 0.72 .

\section{Equity $\left(\mathbf{P I}_{\mathrm{E}}\right)$}

The average value $\mathrm{PI}_{\mathrm{E}}$ in Panam canal command less than one decade delayed cropping pattern for the year 2015-16 was 0.749 , which falls above the upper limits accounting to 'poor' performance. The higher values of $\mathrm{PI}_{\mathrm{E}}$ indicate inequitable distribution. The monthly $\mathrm{PI}_{\mathrm{E}}$ values for the crop year 2015-16 are presented in figure 13 .

\section{Performance measures of panam canal command under two decade delayed cropping pattern during}

\section{Adequacy $\left(\mathbf{P I}_{\mathbf{A}}\right)$}

The Adequacy Index for the Panam canal Irrigation project under two decade delayed cropping pattern in the year 2015-16 is presented in figure 14. The Adequacy of Panam canal command during Rabi season was found to be less than 0.80 which indicate 'poor' performance. Overall, with an average value of $\mathrm{PI}_{\mathrm{A}}$ as 0.48 in Panam Canal Irrigation project indicates a 'poor' performance of the system as far as the adequacy is concerned. The low values of $\mathrm{PI}_{\mathrm{A}}$ were mainly due to uneven distribution of irrigation water supply in the Rabi season.

\section{Efficiency $\left(\mathbf{P I}_{\mathrm{EF}}\right)$}

The average value of $\mathrm{PI}_{\mathrm{EF}}$ in Panam canal Command for the year 2015-16 was 0.87 that indicates a 'good' performance. The $\mathrm{PI} \mathrm{IF}_{\mathrm{EF}}$ values were in range of 0.85-1.0 during month 
of November, January, February and March that indicates a 'good' performance. The $\mathrm{PI}_{\mathrm{EF}}$ values were equal to 1.0 during November. It indicates that the system was efficient to meet the requirements of the region. The $\mathrm{PI}_{\mathrm{EF}}$ value was in range of $0.70-0.84$ in the month of December that indicates 'fair' performance. The monthly $\mathrm{PI}_{\mathrm{EF}}$ values during the crop year 2015-16 are presented in figure 15.

\section{Dependability $\left(\mathbf{P I}_{\mathbf{D}}\right)$}

The Performance index relative to dependability was done based on their respective turns for year 2015-16 in order to assess the dependency of the farmers on canal water over the year within the Panam Canal Command. The Spatial Variations in terms of $\mathrm{PI}_{\mathrm{D}}$ in the Panam canal for the year 2015-16 were worked out and are presented in figure 16. During the year 2015-16, the calculated values of $\mathrm{PI}_{\mathrm{D}}$ were above 0.2 , indicating 'poor' performance in terms of dependability of the system. It indicates that the water deliveries were not uniform over time in accordance to demand, thus poor timeliness. The average value of $\mathrm{PI}_{\mathrm{D}}$ for the year 2015-16 was 0.74 .

\section{Equity $\left(\mathbf{P I}_{\mathrm{E}}\right)$}

The average value $\mathrm{PI}_{\mathrm{E}}$ in Panam canal command for the year 2015-16 was 0.73, which falls above the upper limits accounting to 'poor' performance. This indicates inequitable distribution. The monthly $\mathrm{PI}_{\mathrm{E}}$ values for the crop year 2015-16 are presented in figure 17 .

Performance measures of panam canal command under one fortnightly advance cropping pattern

\section{Adequacy $\left(\mathbf{P I}_{\mathbf{A}}\right)$}

The Adequacy Index for the Panam canal
Irrigation project under one fortnightly advance cropping pattern in the year 2015-16 is presented in figure 18. The Adequacy of Panam canal command during Rabi season was found to be less than 0.80 which indicate 'poor' performance. Overall, with an average value of $\mathrm{PI}_{\mathrm{A}}$ as 0.47 in Panam Canal Irrigation project indicates a 'poor' performance of the system as far as the adequacy is concerned. The low values of $\mathrm{PI}_{\mathrm{A}}$ were mainly due to uneven distribution of irrigation water supply in the Rabi season.

\section{Efficiency $\left(\mathbf{P I}_{\mathbf{E F}}\right)$}

The average value of $\mathrm{PI}_{\mathrm{EF}}$ in Panam canal Command for the year 2015-16 was 0.88 that indicates a 'good' performance. The $\mathrm{PI}_{\mathrm{EF}}$ values were equal to 1.0 during November. It indicates that the system was efficient to meet the requirements of the region. The $\mathrm{PI}_{\mathrm{EF}}$ values was in range of 0.85 to 1.0 during month of October, November, December and January which indicates that a 'good' performance. The monthly $\mathrm{PI}_{\mathrm{EF}}$ values during the crop year 2015-16 are presented in figure 19.

\section{Dependability $\left(\mathbf{P I}_{\mathbf{D}}\right)$}

The Performance index relative to dependability was done based on their respective turns for year 2015-16 in order to assess the dependency of the farmers on canal water over the year within the Panam canal command. The spatial variations in terms of $\mathrm{PI}_{\mathrm{D}}$ in the Panam canal for the year 2015-16 were worked out and are presented in figure 20.

During the year 2015-16, the calculated values of $\mathrm{PI}_{\mathrm{D}}$ were above 0.2 , indicating 'poor' performance in terms of dependability of the system. It indicates that the water deliveries were not uniform over time in accordance to demand, thus poor timeliness. 
The average value of $\mathrm{PI}_{\mathrm{D}}$ for the year 2015-16 was 0.83 .

\section{Equity $\left(\mathrm{PI}_{\mathrm{E}}\right)$}

The average value of $\mathrm{PI}_{\mathrm{E}}$ in Panam Canal Command for the year 2015-16 was 0.81, which falls above the upper limits accounting to 'poor' performance. The higher values of $\mathrm{PI}_{\mathrm{E}}$ indicates inequitable distribution. The monthly $\mathrm{PI}_{\mathrm{E}}$ values for the crop year 2015-16 are presented in figure 21 .

Performance measures of panam canal command under one fortnightly delayed cropping pattern

\section{Adequacy $\left(\mathbf{P I}_{\mathbf{A}}\right)$}

The Adequacy Index for the Panam canal Irrigation Project under one fortnightly delayed cropping pattern in the year 2015-16 is presented in figure 22. The Adequacy of Panam canal command during Rabi season was found to be less than 0.80 which indicate 'poor' performance. Overall, with an average value of $\mathrm{PI}_{\mathrm{A}}$ as 0.47 in Panam Canal Irrigation project indicates a 'poor' performance of the system as far as the adequacy is concerned. The low values of $\mathrm{PI}_{\mathrm{A}}$ were mainly due to uneven distribution of irrigation water supply in the Rabi season.

\section{Efficiency $\left(\mathbf{P I}_{\mathrm{EF}}\right)$}

The average value of $\mathrm{PI}_{\mathrm{EF}}$ in Panam canal Command for the year 2015-16 was 0.92 that indicates a 'good' performance. The $\mathrm{PI} \mathrm{IF}_{\mathrm{EF}}$ values were equal to 1.0 during November. It indicates that the system was efficient to meet the requirements of the region. The $\mathrm{PI}_{\mathrm{EF}}$ values was in range of 0.85 to 1.0 during month of November, December, January and February which indicates that a 'good' performance. The $\mathrm{PI}_{\mathrm{EF}}$ value was in range of 0.70-0.84 which indicates 'fair' performance. The monthly $\mathrm{PI}_{\mathrm{EF}}$ values during the crop year 2015-16 are presented in figure 23 .

Table.1 Properties of soils in the study area

\begin{tabular}{|c|c|c|c|}
\hline Sr. No. & Soil Properties & & Details \\
\hline 1. & Physical properties & $\begin{array}{l}\text { Soil Type } \\
\text { Surface colour } \\
\text { Depth of the soil }\end{array}$ & $\begin{array}{l}\text { Medium black to loamy sand (Goradu) } \\
\text { soils } \\
\text { Reddish brown to insity soil of East } \\
\text { dark Brown to dark yellowish brown } \\
\text { and grey in alluvial. } \\
0 \text { to } 25 \mathrm{~cm} \text { in hilly area and } 90 \text { to } 180 \\
\mathrm{~cm} \text { in other areas }\end{array}$ \\
\hline 2. & Chemical properties & $\begin{array}{l}\mathrm{EC}(\text { micromhos } / \mathrm{cm}) \\
\mathrm{pH} \\
\mathrm{N} \\
\mathrm{P} \\
\mathrm{K}\end{array}$ & $\begin{array}{l}\text { More than } 10 \text { in most of the area. } \\
7.9-8.2 \\
\text { Low } \\
\text { Medium } \\
\text { High }\end{array}$ \\
\hline
\end{tabular}


Table.2 Irrigation details of 23/R, 27/R, 28/R and 29/R and 33/R distributaries

\begin{tabular}{|l|c|c|c|c|}
\hline Name of Canal & $\begin{array}{c}\text { Off taking of Panam } \\
\text { main canal (m) }\end{array}$ & Length (m) & $\begin{array}{c}\text { Discharge } \\
\text { (cu-f/s) }\end{array}$ & $\begin{array}{c}\text { Cultural } \\
\text { Command Area } \\
\text { (ha) }\end{array}$ \\
\hline 23/R distributary & 38300 & 7000 & 65 & 2070 \\
\hline 27/R distributary & 62850 & 10500 & 35 & 1625 \\
\hline 28/R distributary & 65945 & 3800 & 12.00 & 649 \\
\hline 29/R distributary & 71965 & 11130 & 36 & 1691 \\
\hline 33/R distributary & 91425 & 3200 & 3 & 149 \\
\hline
\end{tabular}

Table.3 Performance standards for irrigation systems (Nam et al., 2016)

\begin{tabular}{|l|l|l|l|}
\hline \multirow{2}{*}{ Measure } & \multicolumn{3}{|c|}{ Performance Classes } \\
\cline { 2 - 4 } & Good & Fair & Poor \\
\hline PI $_{\mathbf{A}}$ & $0.90-1.0$ & $0.80-0.89$ & $<0.80$ \\
$\mathbf{P I}_{\text {EF }}$ & $0.85-1.0$ & $0.70-0.84$ & $<0.70$ \\
PI $_{\text {D }}$ & $0-0.10$ & $0.11-0.20$ & $>0.20$ \\
PI $_{\text {E }}$ & $0-0.10$ & $0.11-0.25$ & $>0.25$ \\
\hline
\end{tabular}

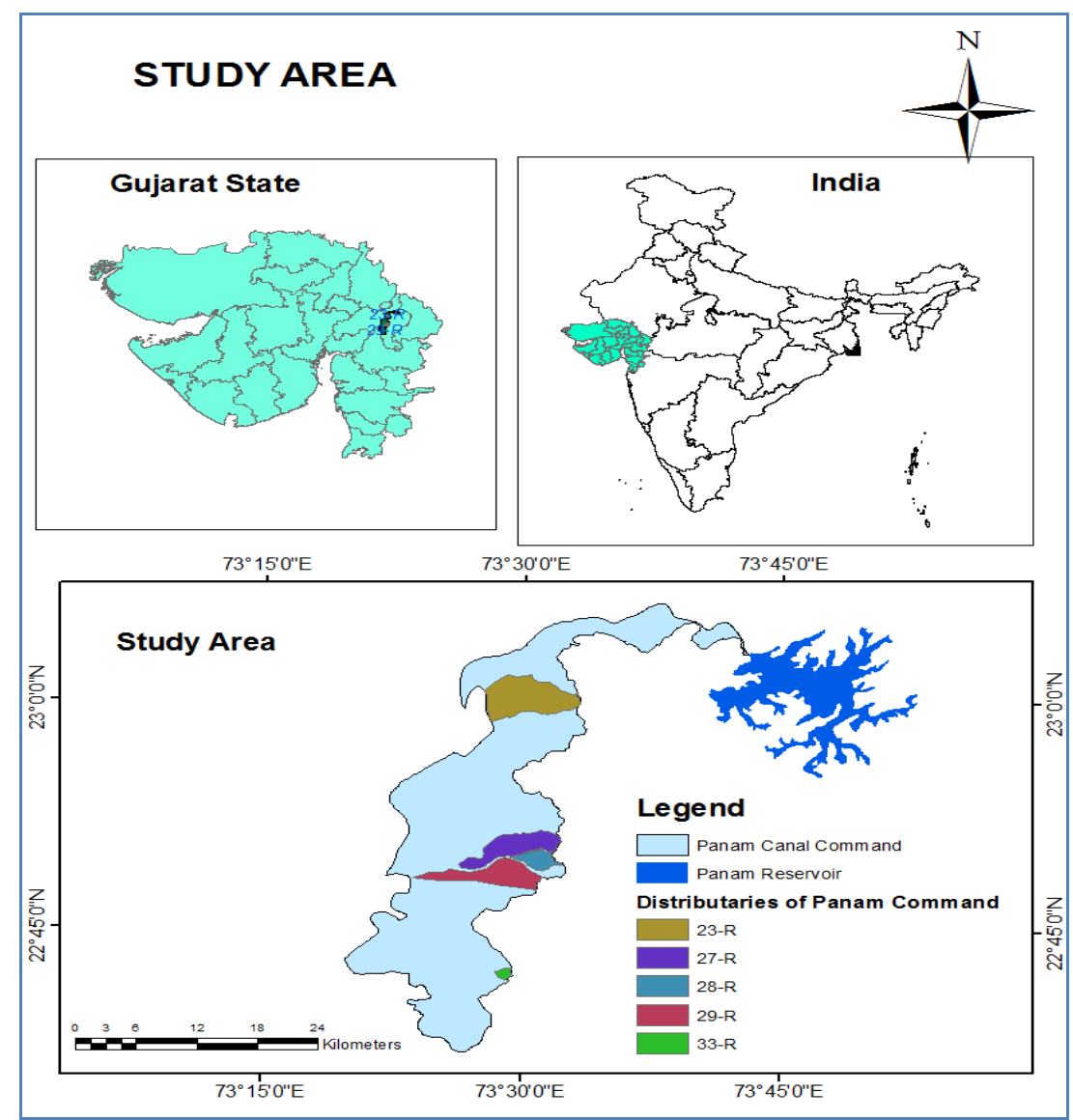

Fig.1 Location map of study area 


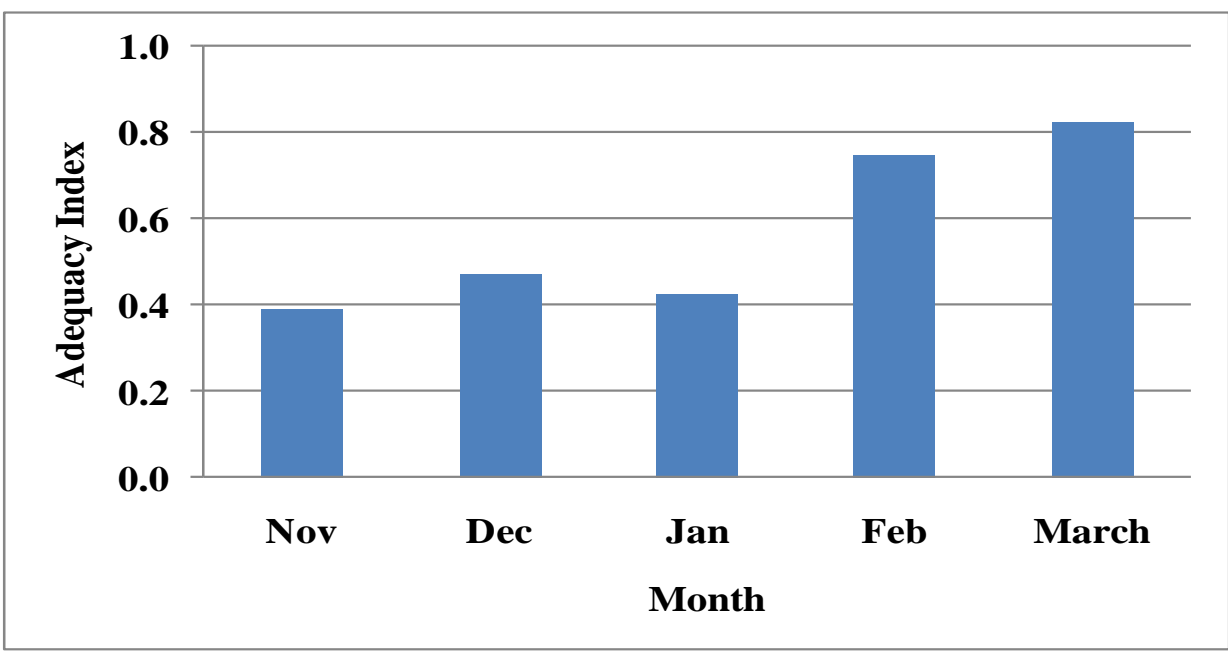

Fig.2 Adequacy Index $\left(\mathrm{PI}_{\mathrm{A}}\right)$ of Panam canal command under existing cropping pattern

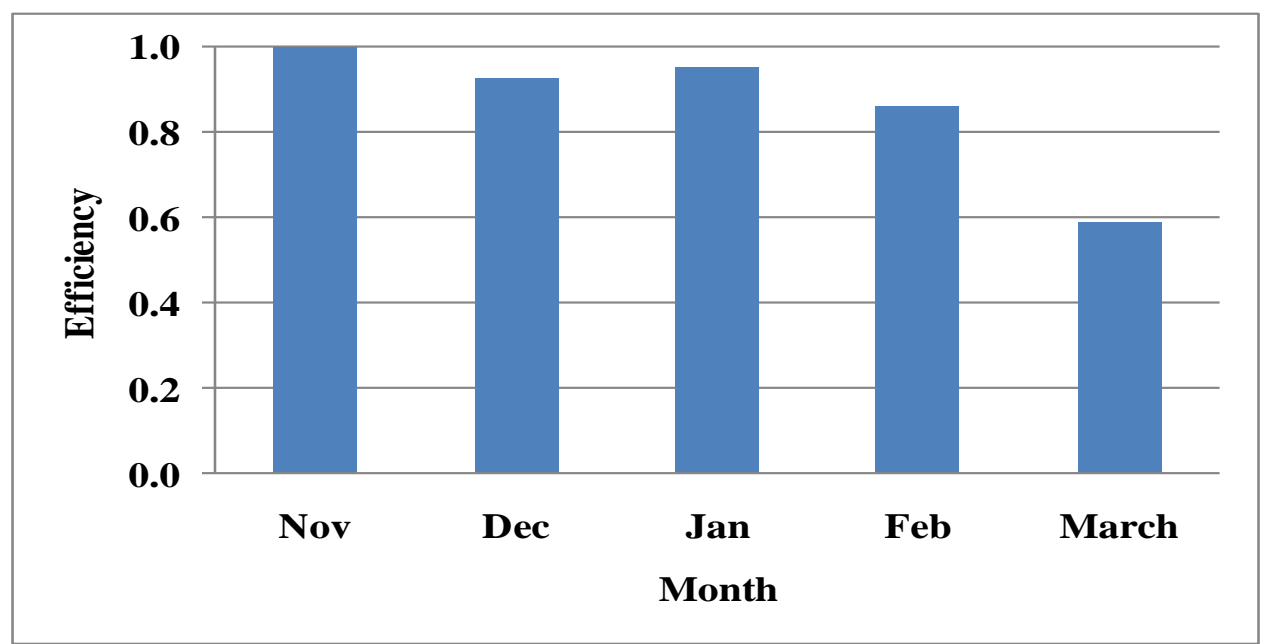

Fig.3 Efficiency of Panam canal command under existing cropping pattern

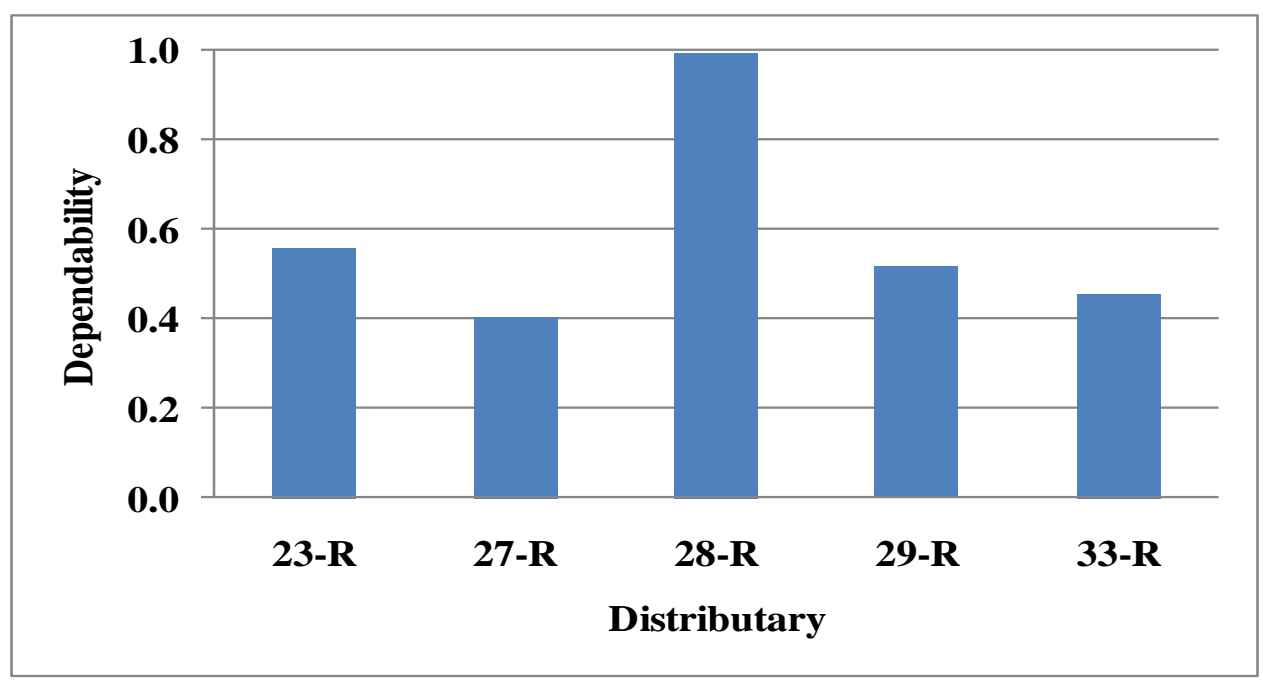

Fig.4 Dependability of Panam canal command under existing cropping pattern 


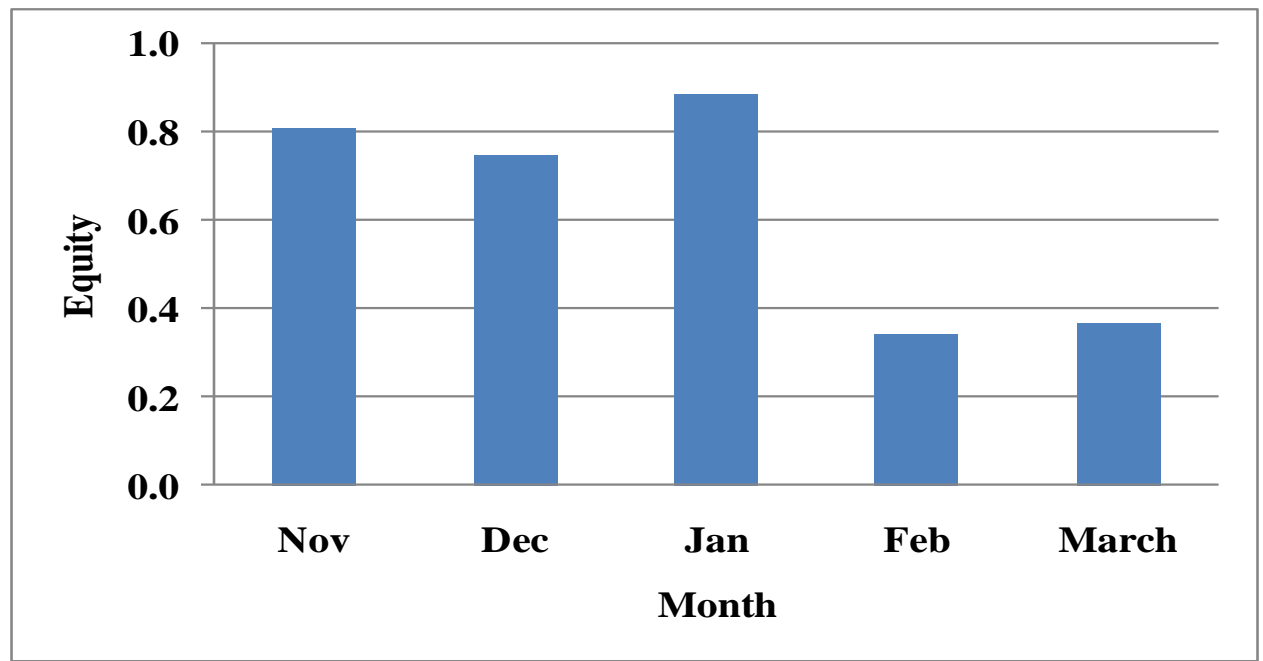

Fig.5 Equity of Panam canal command under existing cropping pattern

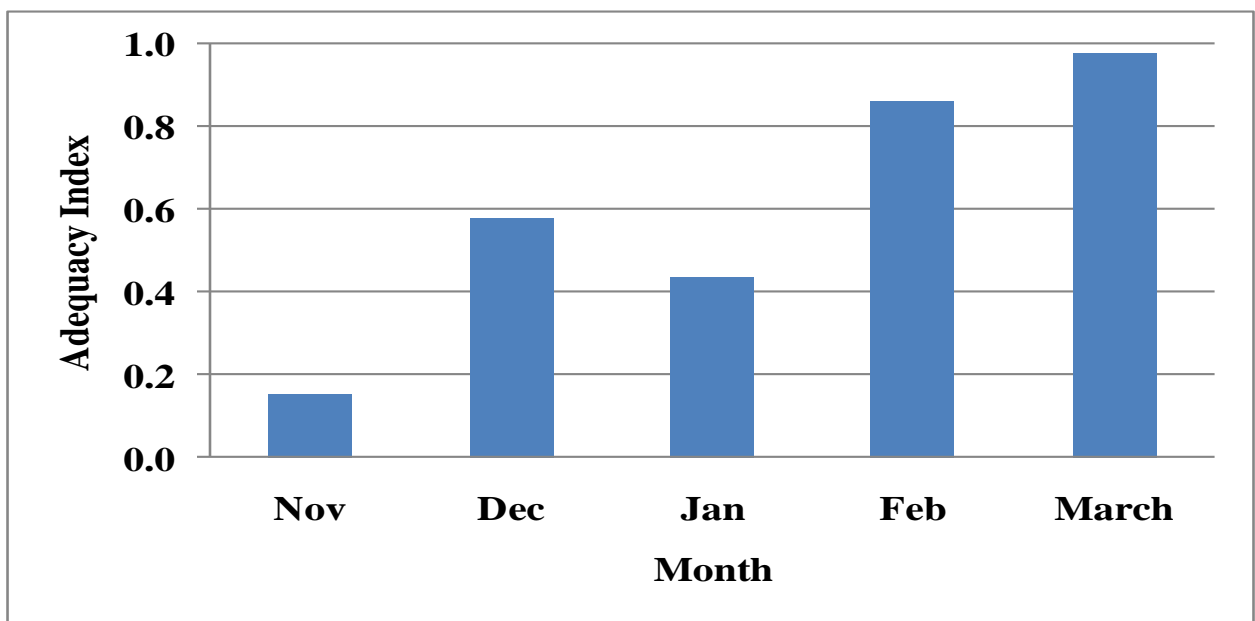

Fig.6 Adequacy Index $\left(\mathrm{PI}_{\mathrm{A}}\right)$ of Panam canal command under one decade advance cropping pattern

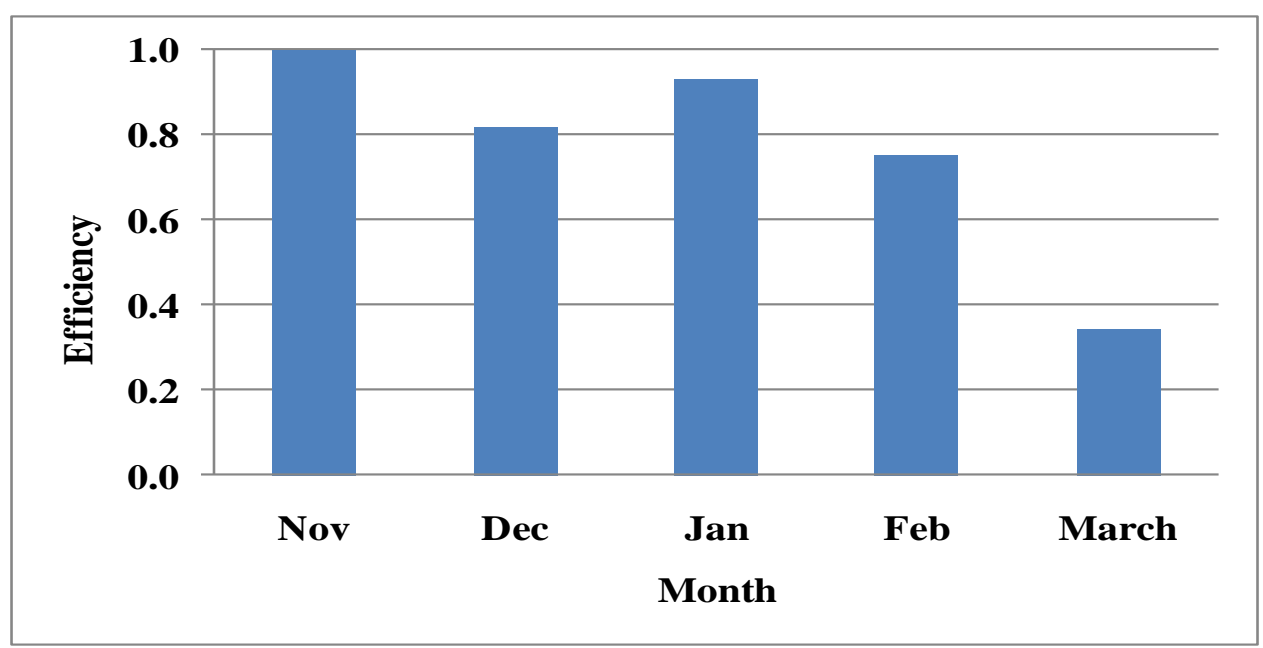

Fig.7 Efficiency of Panam canal command under one decade advance cropping pattern 


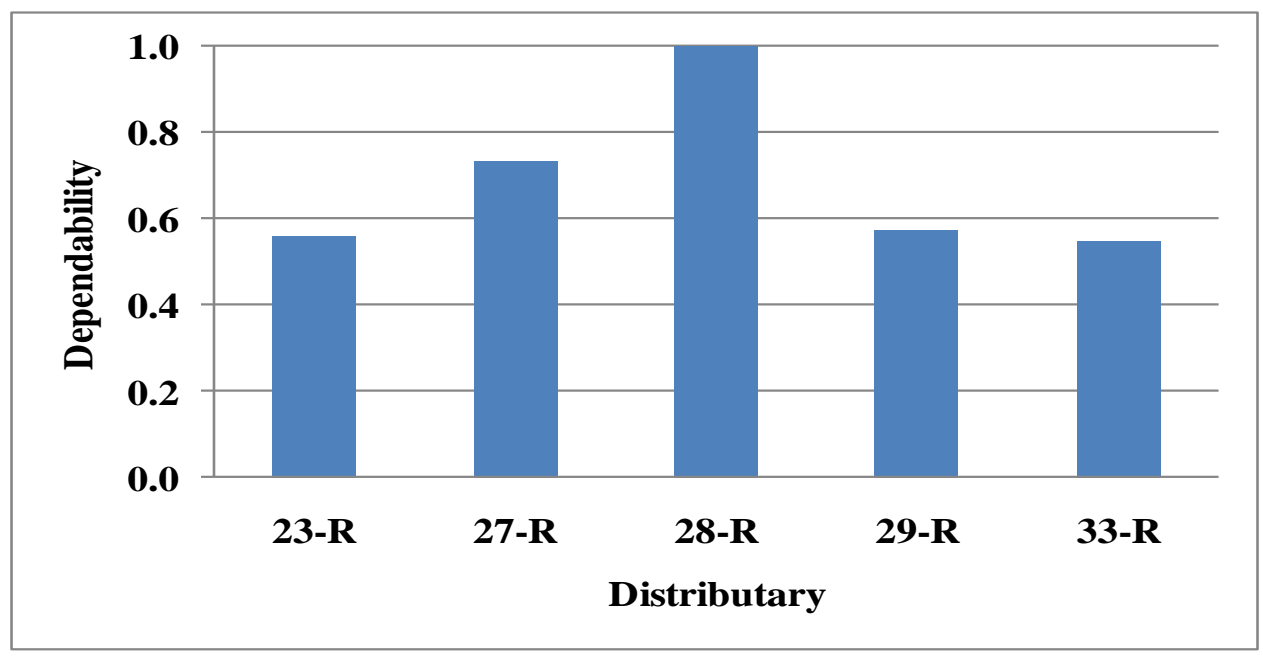

Fig.8 Dependability of Panam canal command under one decade advance cropping pattern

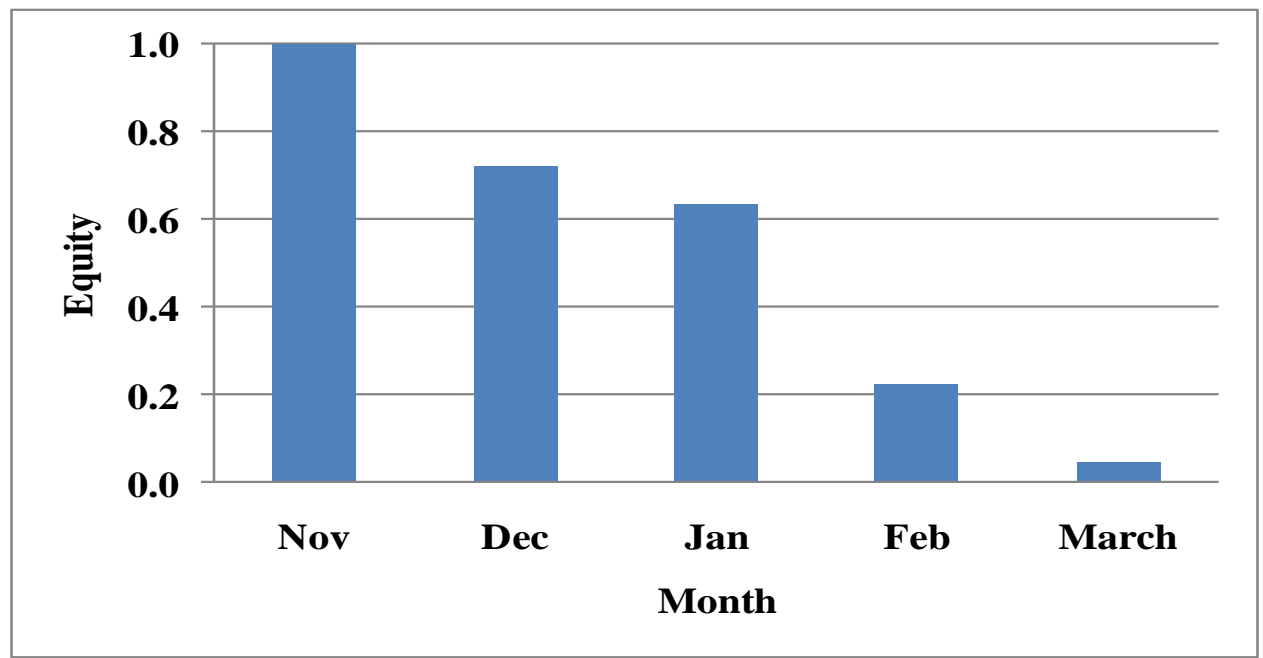

Fig.9 Equity of Panam canal command under one decade advance cropping pattern

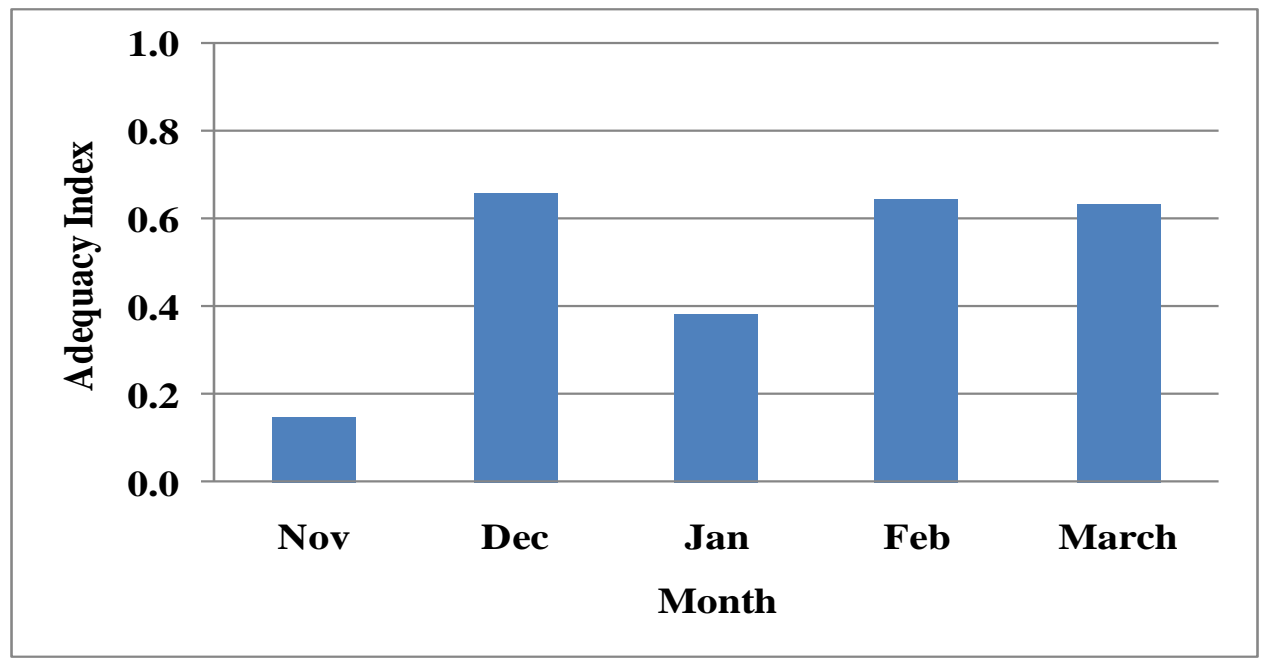

Fig.10 Adequacy Index $\left(\mathrm{PI}_{\mathrm{A}}\right)$ of Panam canal command under one decade delayed cropping pattern 


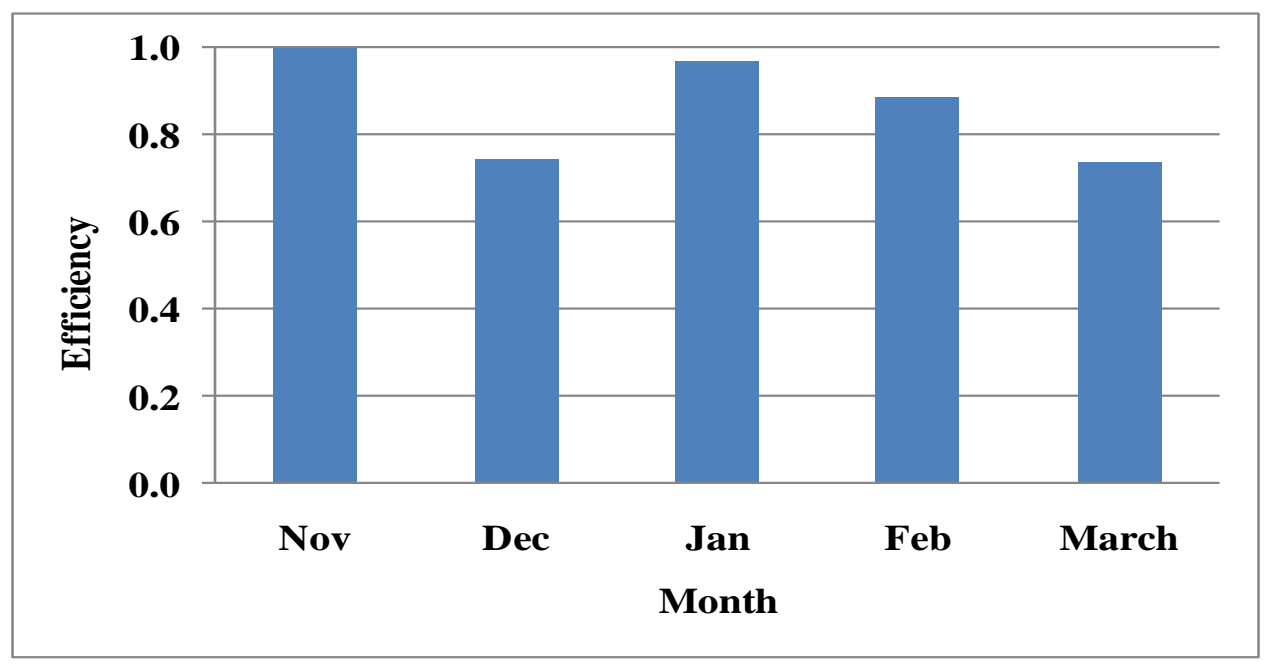

Fig.11 Efficiency of Panam canal command under one decade delayed cropping pattern

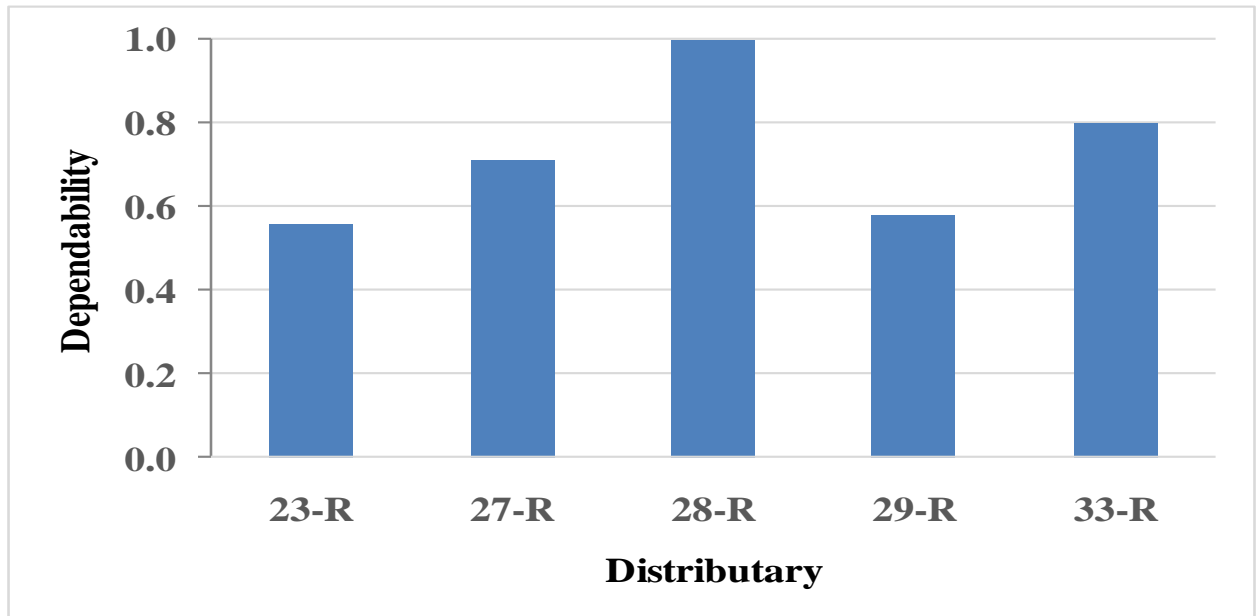

Fig.12 Dependability of Panam canal command under one decade delayed cropping pattern

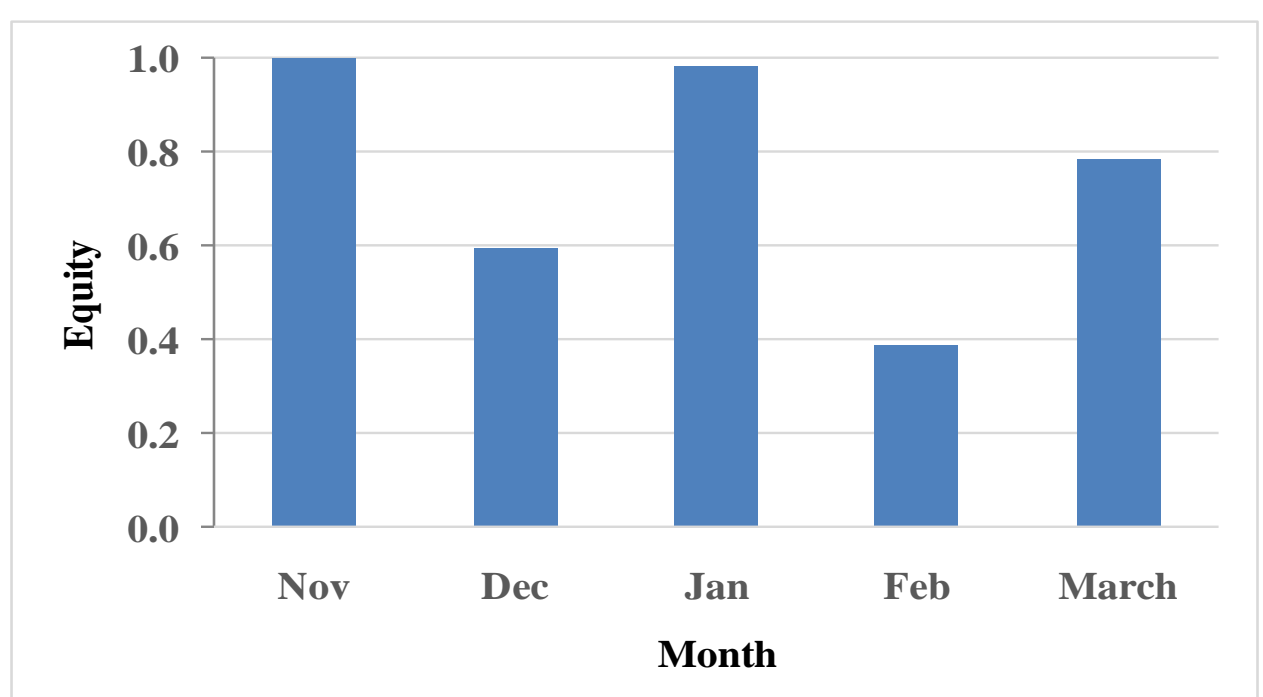

Fig.13 Equity of Panam canal command under one decade delayed cropping pattern 


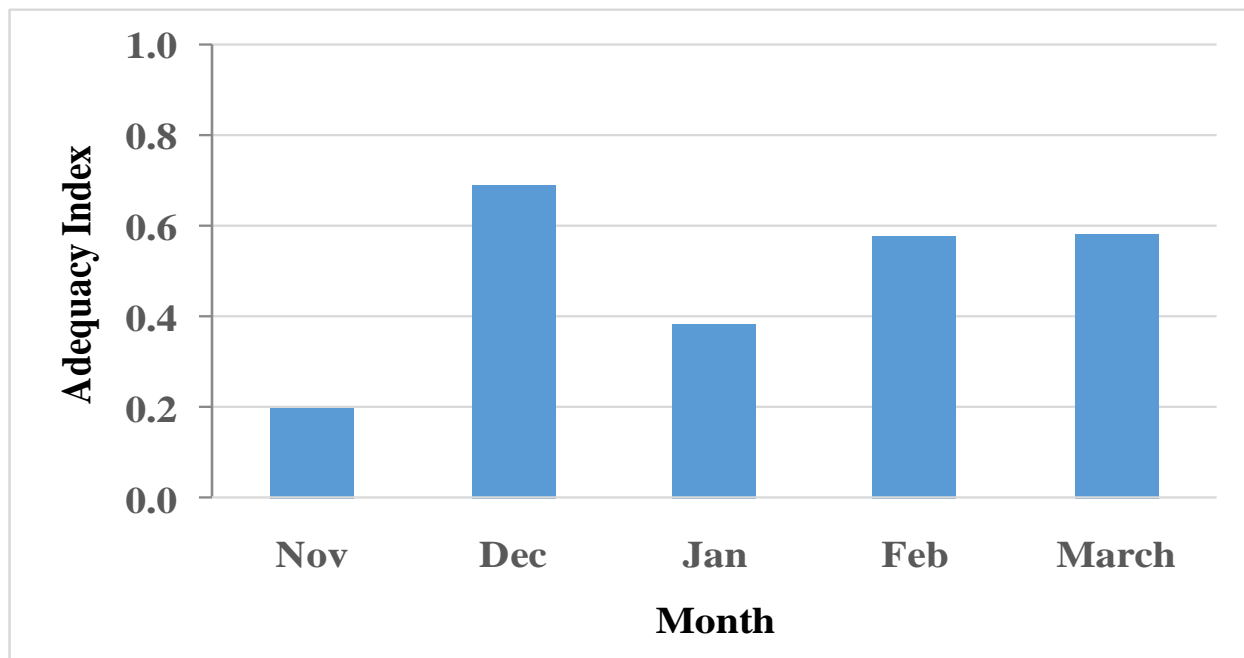

Fig.14 Adequacy Index $\left(\mathrm{PI}_{\mathrm{A}}\right)$ of Panam canal command under two decade delayed cropping pattern

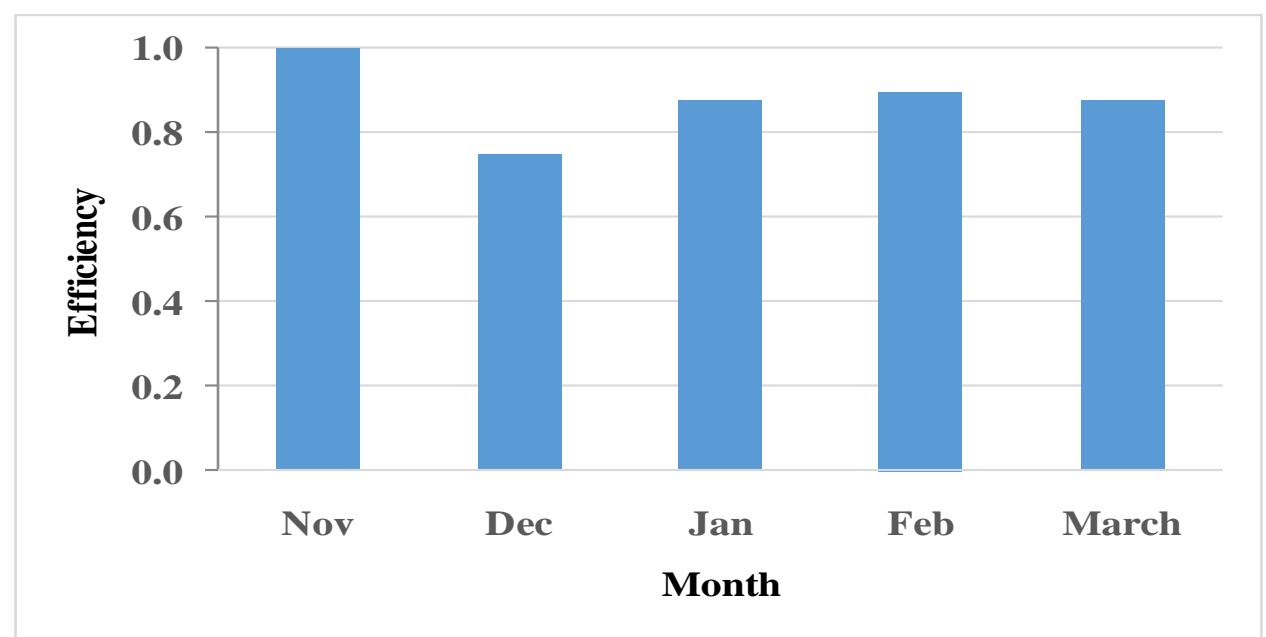

Fig.15 Efficiency of Panam canal command under two decade delayed cropping pattern

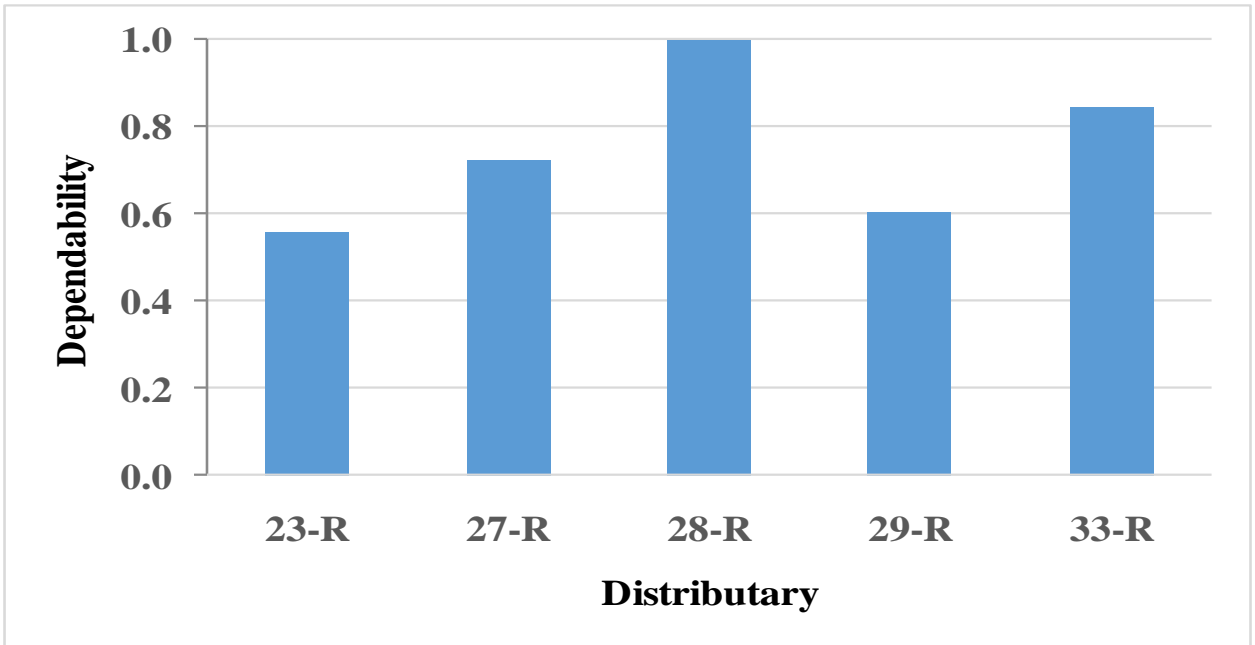

Fig.16 Dependability of Panam canal command under two decade delayed cropping pattern 


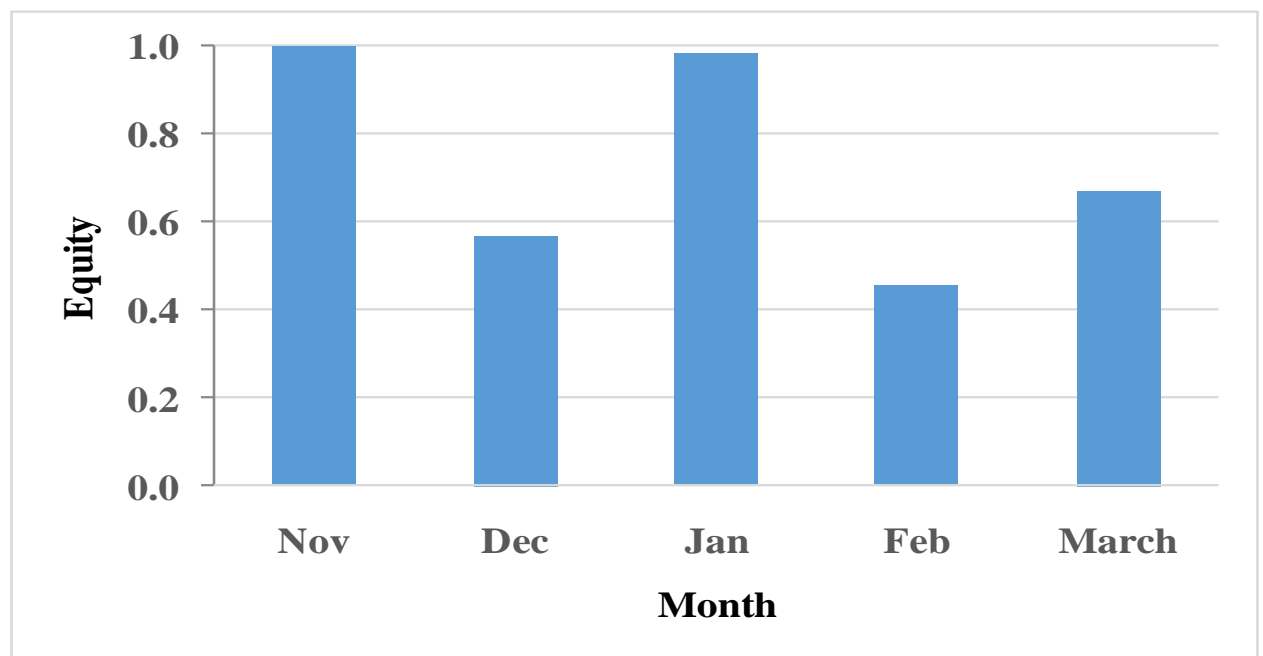

Fig.17 Equity of Panam canal command under two decade delayed cropping pattern

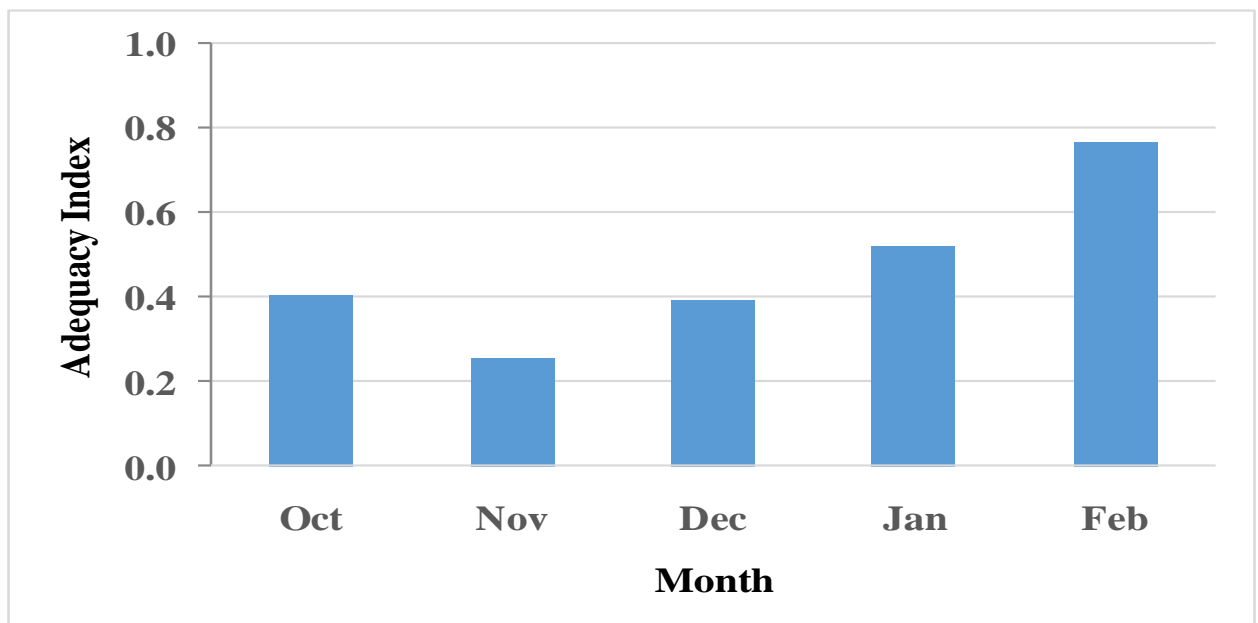

Fig.18 Adequacy Index $\left(\mathrm{PI}_{\mathrm{A}}\right)$ of Panam canal command under one fortnightly advance cropping pattern

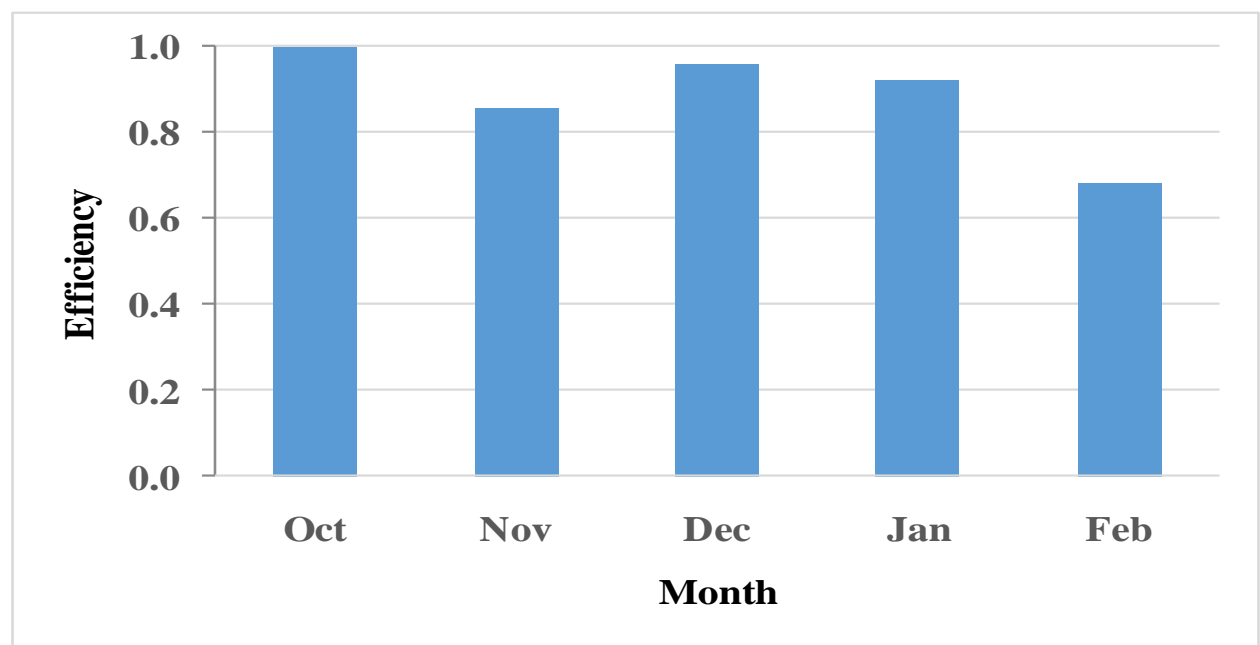

Fig.19 Efficiency of Panam canal command under one fortnightly advanced cropping pattern 


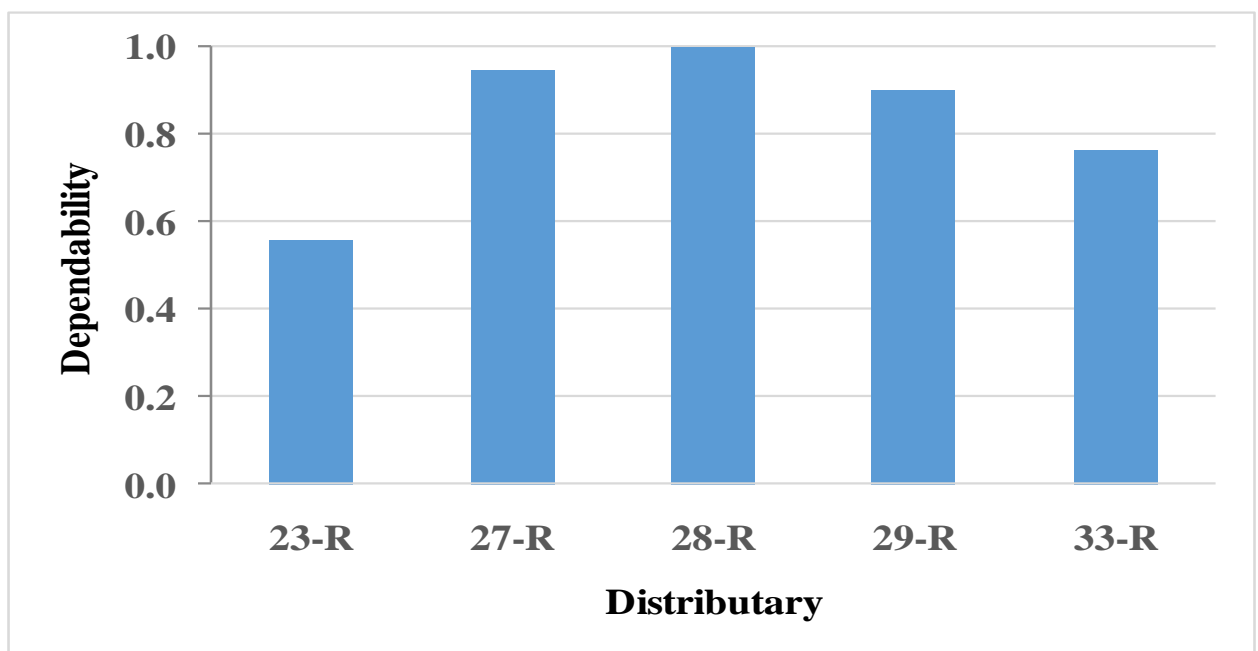

Fig.20 Dependability of Panam canal command under one fortnightly advanced cropping pattern

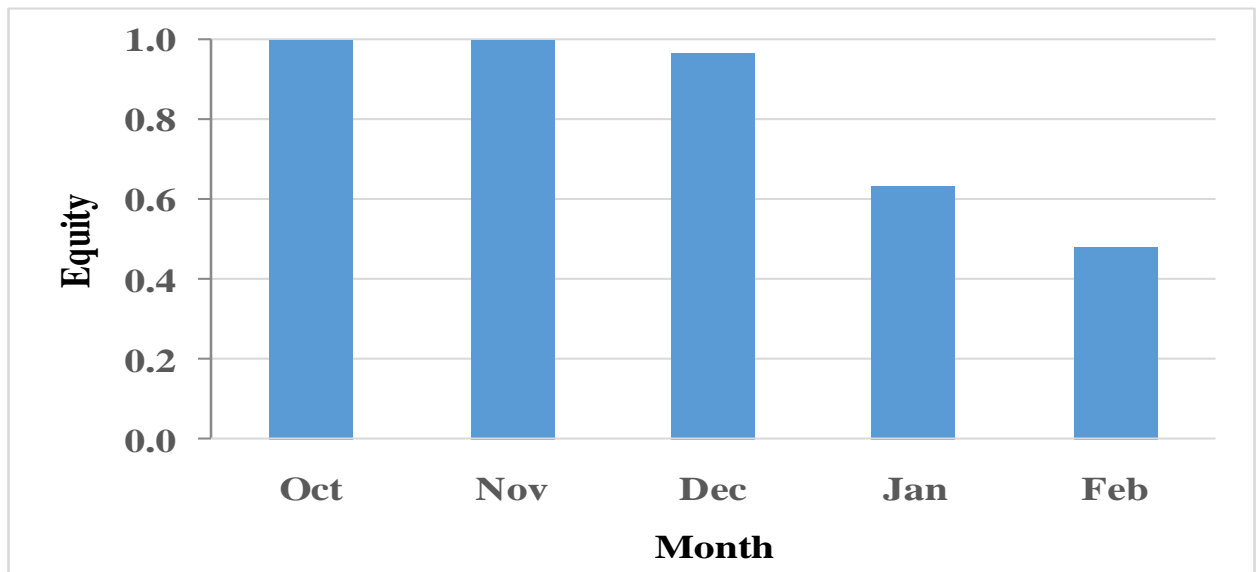

Fig.21 Equity of Panam canal command under one fortnightly advance cropping pattern

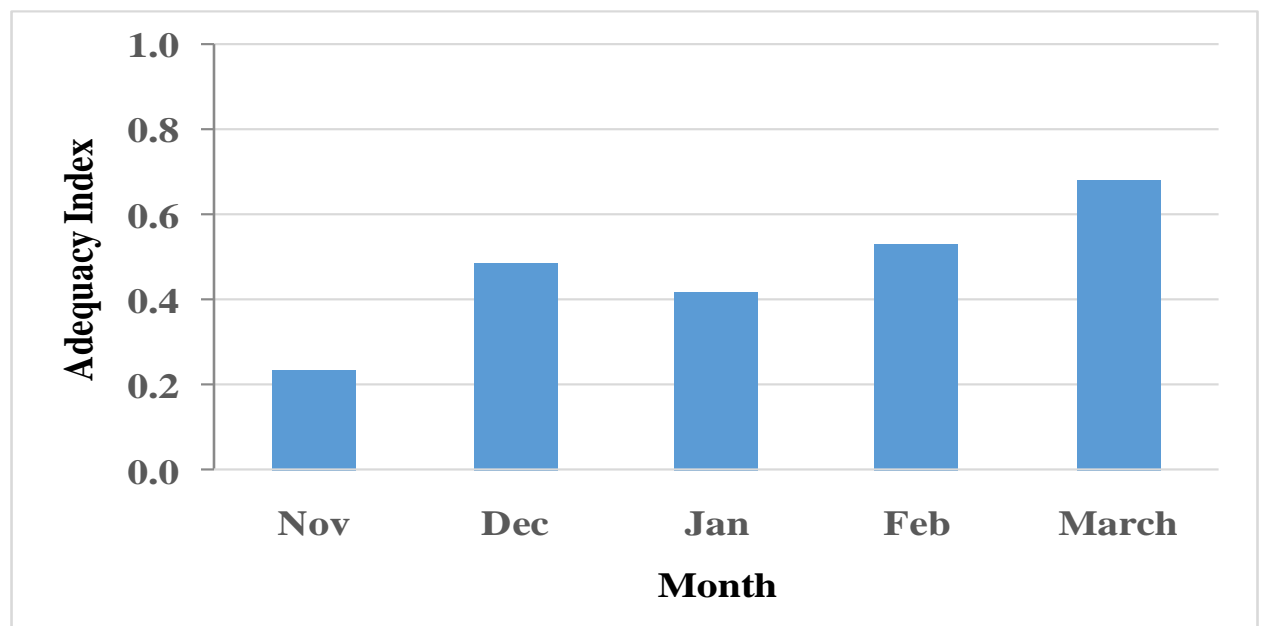

Fig.22 Adequacy Index $\left(\mathrm{PI}_{\mathrm{A}}\right)$ of Panam canal command under one fortnightly delayed cropping pattern 


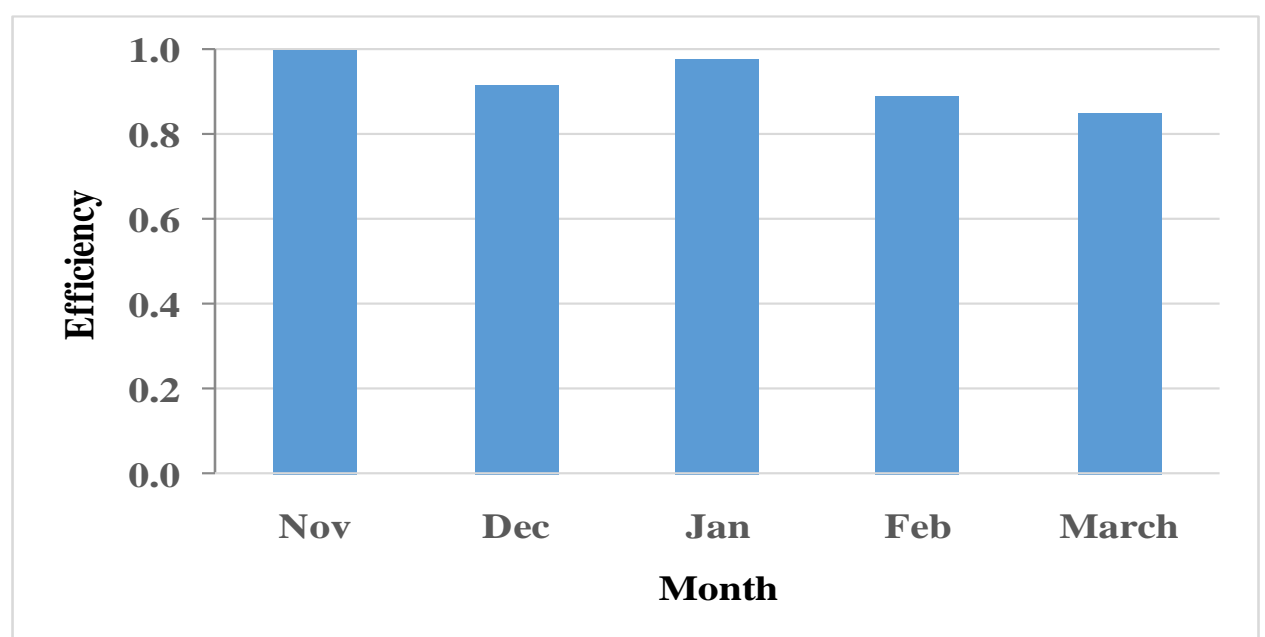

Fig.23 Efficiency of Panam canal command under one fortnightly delayed cropping pattern

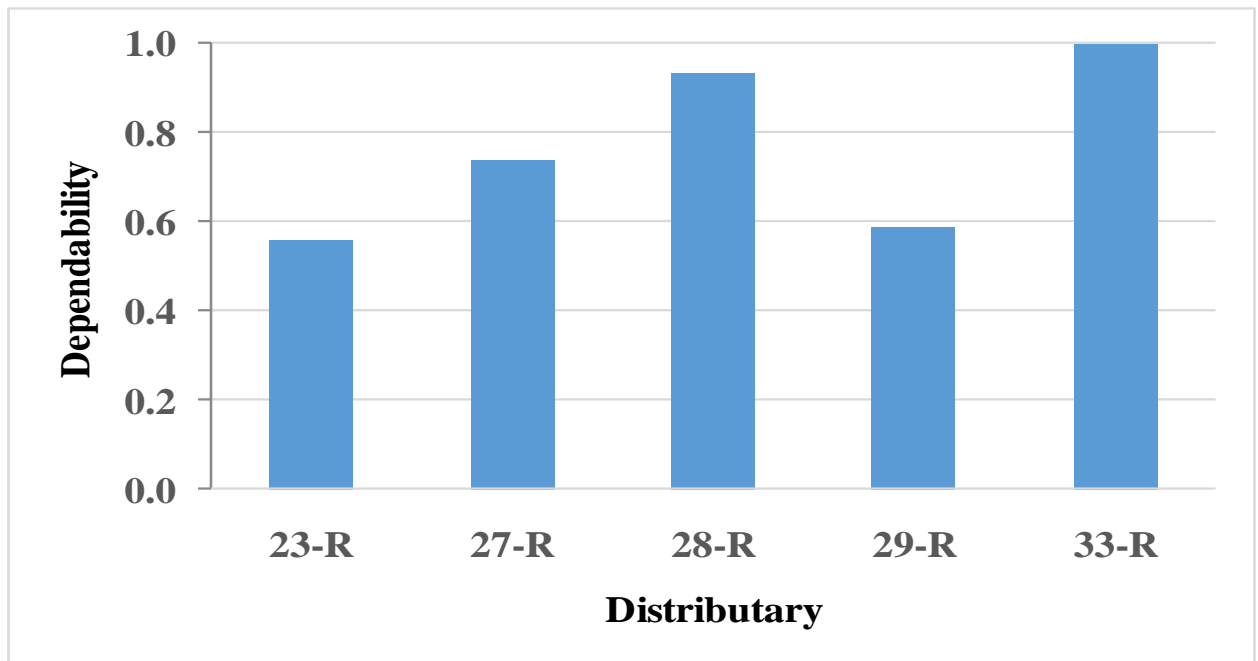

Fig.24 Dependability of Panam canal command under one fortnightly delayed cropping pattern

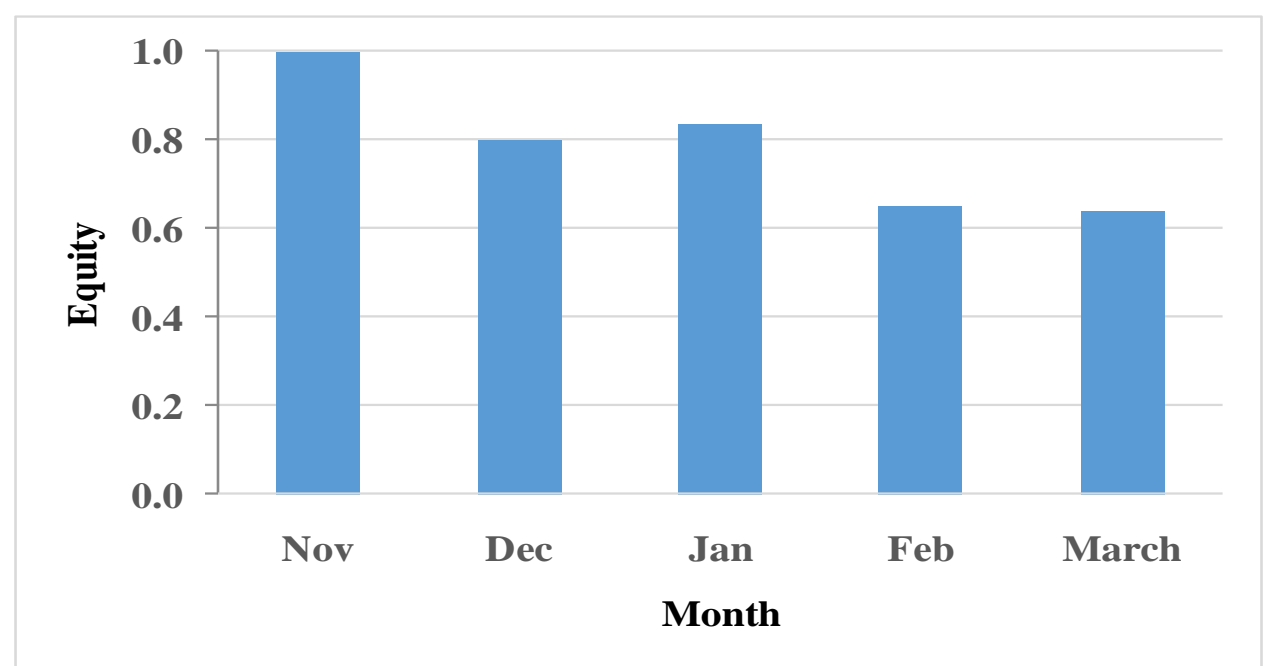

Fig.25 Equity of Panam canal command under one fortnightly delayed cropping pattern 


\section{Dependability ( PI $\left._{\mathbf{D}}\right)$}

The Performance index relative to dependability was done based on their respective turns for year 2015-16 in order to assess the dependency of the farmers on canal water over the year within the Panam Canal Command. The spatial variations in terms of $\mathrm{PI}_{\mathrm{D}}$ in the Panam canal for the year 2015-16 were worked out and are presented in figure 24. During the year 2015-16, the calculated values of $\mathrm{PI}_{\mathrm{D}}$ were above 0.2 , indicating 'poor' performance in terms of dependability of the system. It indicates that the water deliveries were not uniform over time in accordance to demand, thus poor timeliness. The average value of $\mathrm{PI}_{\mathrm{D}}$ for the year 2015-16 was 0.76 .

\section{Equity $\left(\mathbf{P I}_{\mathbf{E}}\right)$}

The average value of $\mathrm{PI}_{\mathrm{E}}$ in Panam Canal Command for the year 2015-16 was 0.78, this falls above the upper limits accounting to 'poor' performance. The higher value of PIE indicates inequitable distribution. The monthly $\mathrm{PI}_{\mathrm{E}}$ values for the crop year 2015-16 are presented in figure 25 . From result, the comparatively better performance in terms of adequacy, efficiency, dependability and equity was found in one decade advanced, one fortnightly delayed, existing and one decade advanced scheduling approach respectively.

\section{Application of research}

Irrigation scheduling for optimum cropping pattern in selected Panam canal command situated in Middle Gujarat.

\section{Abbreviations}

cu m: cubic meter, b cu m: billion cubic meters, CCA: Cultural Command Area (CCA), cu-f/s: Cubic feet Per second, adequacy $\left(\mathrm{PI}_{\mathrm{A}}\right), \quad$ efficiency $\left(\mathrm{PI}_{\mathrm{EF}}\right)$, dependability $\left(\mathrm{PI}_{\mathrm{D}}\right)$ and equity $\left(\mathrm{PI}_{\mathrm{E}}\right)$

\section{Acknowledgement/funding}

Author thankful to Department of Irrigation and Drainage Engineering, College of Agricultural Engineering and Technology, Anand Agricultural University, Godhra, 389001, Gujarat, India.

\section{References}

1. Planning Commission (2002) Report of the steering committee on irrigation for the tenth five year plan (2002-2007). Govt of India, New Delhi (India).

2. Raul, S. K., Panda, S. N., Hollaender, H. and Billib, M. (2011). Integrated water resource management in a major canal command in eastern India. Journal of Hydrological process 25:2551-2562.

3. WWAP (2012) Facts and figures: Managing water under uncertainty and risk. United Nations World Water Development Report 4, UNESCO, Paris/London.

4. Bos, M. G., Burton, M. A. and Molden, D. J. (2005) Irrigation and Drainage Performance Assessment. Practical Guidelines. CABI Publishing, $\quad C A B$ International Wallingford, Oxfordshire OX10 8DE, UK.pp. 158.

5. Molden, D., Burton, M. and Bos, M. G. (2007) Performance assessment, irrigation service delivery and poverty reduction: benefits of improved system management. Irrigation and Drainage 56(2-3): 307320.

6. Saxena, R. P. (2012) Impacts of Kangsabati Project, India. In Impacts of Large Dams: a Global Assessment; Edited by Tortajada, C., Altinbilek, D and Biswas, A. K. Published by Springer Berlin Heidelberg, 277-298. doi: 10.1007/ 978-3-642-23571-9_13. 
7. Molden, D. J. and Gates, T. K. (1990) Performance measures for evaluation of irrigation-water-delivery systems. Journal of Irrigation and Drainage Engineering 116: 804-823.
8. Nam, Won-ho., Hong, Eun-Mi. and Choli, Jin-Yong. (2016) Assessment of water delivery efficiency in irrigation canals using performance indicators. Irrigation Science. 34(2): 129-139.

\section{How to cite this article:}

Deepak Kumar and Tiwari, M. K. 2020. Performance Evaluation of Panam Canal Delivery System in Middle Gujarat. Int.J.Curr.Microbiol.App.Sci. 9(04): 1733-1752. doi: https://doi.org/10.20546/ijcmas.2020.904.204 